\title{
Author Correction: HIF1 1 inhibition facilitates Leflunomide-AHR-CRP signaling to attenuate bone erosion in CRP-aberrant rheumatoid arthritis
}

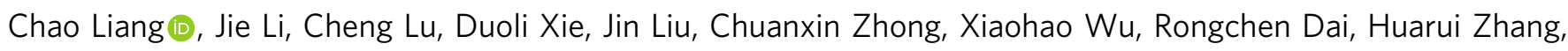
Daogang Guan, Baosheng Guo, Bing He, Fangfei Li, Xiaojuan He, Wandong Zhang, Bao-Ting Zhang, Ge Zhang \& Aiping Lu

Correction to: Nature Communications https://doi.org/10.1038/s41467-019-12163-z, published online 8 October 2019.

This Article contained errors in Figs. 4i and 5a, for which the authors apologise. The lanes labelled ARNT (lower row) in Fig. 4i and HIFlalpha in Fig. 5a were not from the membranes used to probe for the other proteins shown in each panel. These have now been replaced with the correct rows from the same membranes. These errors were reproduced in the source data file that contains the uncropped membranes. The errors did not affect the conclusions of the manuscript. They have now been corrected both the PDF and HTML versions of the Article, and the Source Data file has been amended to include the correct images of the respective uncropped membranes.

Published online: 22 June 2020

(i) Open Access This article is licensed under a Creative Commons Attribution 4.0 International License, which permits use, sharing, adaptation, distribution and reproduction in any medium or format, as long as you give appropriate credit to the original author(s) and the source, provide a link to the Creative Commons license, and indicate if changes were made. The images or other third party material in this article are included in the article's Creative Commons license, unless indicated otherwise in a credit line to the material. If material is not included in the article's Creative Commons license and your intended use is not permitted by statutory regulation or exceeds the permitted use, you will need to obtain permission directly from the copyright holder. To view a copy of this license, visit http://creativecommons.org/licenses/by/4.0/.

(c) The Author(s) 2020 